\title{
Biofouling
}

2002, Volume 18, Issue 3, Pages 205-215

http://dx.doi.org/10.1080/08927010290010137

(c) 2002 Taylor \& Francis Ltd

The original publication is available at http://www.tandf.co.uk/journals/

\section{Screening of Marine Algal Extracts for Anti-settlement Activities against Microalgae and Macroalgae}

\author{
Claire HELLIO ${ }^{1,2, *}$, Jean Pascal BERGE ${ }^{3}$, Claude BEAUPOIL ${ }^{2}$, Yves LE GAL $^{2}$, \\ Nathalie BOURGOUGNON ${ }^{4}$
}

${ }^{1}$ Department of Marine Sciences \& Coastal Management, University of Newcastle, Ridley Building, Newcastle upon Tyne NE1 7RU, UK. E-mail : c.g.a.hellio@ncl.ac.uk, Fax : +44-191-222-7891

${ }^{2}$ Laboratoire de Biologie Marine, FRE 2125 CNRS-UBO-MNHN, BP 225, 29182 Concarneau, France.

${ }^{3}$ IFREMER, Nantes. Laboratoire Biotechnologie et Molécules Marines, Département Valorisation des Produits, IFREMER, BP21105, 44311 Nantes cedex 03, France.

${ }^{4}$ Laboratoire de Biologie et Chimie Moleculaires, Centre de Recherche et d'Enseignement Yves Coppens, Campus de Tohannic, BP 573, 56017 Vannes, France.

*: Corresponding author : fax: p44-191-222-7891; e-mail: c.g.a.hellio@ncl.ac.uk

\begin{abstract}
:
The ban on the use of TBT-based antifouling paints for boats under $25 \mathrm{~m}$ in length has lead to a search for new non-toxic antifoulants. One of the most promising alternative technologies to heavy metal based antifouling paint is the development of antifouling coatings whose active ingredients are naturally occurring compounds from marine organisms. This is based on the principle that marine organisms are also facing the problem of the presence of epibionts on their own surface. In this study, the antifouling activity of a series of aqueous, ethanolic and dichloromethane extracts from 30 algae from the North East Atlantic coast was investigated. The extracts were tested in laboratory assays against species representatives of two major groups of fouling organisms: macroalgae and microalgae. The activity of several extracts was comparable to that of heavy metals and biocides (such as TBTO and $\mathrm{CuSO}_{4}$ ) currently used in antifouling paints and their absence of toxicity against larvae of oysters and sea urchins suggest a potential for novel active ingredients.
\end{abstract}

Key words: Antifouling, antialgal, microalgae, macroalgae, screening, settlement, spores. 


\section{Introduction}

Marine algae play an important role in the fouling of a wide range of immersed artificial substrates; particularly on substrates in shallow water where there is sufficient light to permit the active growth of algae. Although there are many diverse phyla of marine algae, only a relatively small number of these are considered to be important as fouling organisms. The three most important phyla economically are undoubtedly the Chlorophyta, Heteroconta (notably the Diatomophyceae) and the Rhodophyta, although one other, the Cyanophyta, are also frequently reported, particularly as primary colonisers (Fletcher, 1980). Microalgae and spores of macroalgae from species such as Enteromorpha intestinalis or Ulothrix zonata settle after the development of a primary film comprising bacteria, with a clear quantitative dominance of benthic diatoms (Abarzua \& Jakubowski, 1995). Uncontrolled adhesion of fouling macroalgae such as green algae of the genera Ulva and Enteromorpha cause serious problems by settling on ships'hulls, power plant cooling systems, aquaculture systems, and other marine infrastructure (Fletcher, 1989; Vanelle \& Le Gal, 1995; Miki et al., 1996; Hattori \& Shizuri, 1996). Current methods of control are primarily based on the use of toxic antifouling paints containing compounds of copper (e.g. cuprous oxide, cuprous thiocyanate), and organotin (e.g., tributyltin oxide, tributyltin fluoride). However, these are not wholly effective, particularly against slime-forming diatom algae, and concern has been expressed about the environmental effects of tributyltin compounds (Alzieu et al. 1980; Bryan et al., 1986; Fletcher, 1989; Jackson, 1991). Due to environmental concerns, the application of triorganotin-based paints has been prohibited and it is expected that the use of cupric oxide paints will be limited in the near future (De Nys et al., 1995).

A promising alternative to heavy metal based paint in the development of antifouling coatings is the use of bioactive ingredients produced by marine organisms (Holmström \& Kjelleberg, 1994 ; Kjelleberg \& Steinberg, 1994). In a marine environment, where all surfaces are constantly exposed to the threat of surface colonisation, many sessile organisms remain relatively free of biofouling. These sedentary organisms control fouling epibionts by effective antifouling mechanisms. Macroalgae are a rich source of natural bioactive products although little has been done to define an ecological role for these compounds (De Nys et al. 1995). It is therefore possible that they possess chemical defences to prevent the colonisation of their surface.

Studies on antifouling mechanisms of marine organisms may provide valuable information for fouling control in marine technology. The use of marine natural products that are capable of inhibiting one or several steps of fouling on ships and others structures may provide a solution to this sensitive environmental issue.

This study is a part of our global research programme carried out in order to find effective natural products against the formation of marine biofilms. In this work, a series of aqueous, ethanol and dichloromethane extracts of 30 marine algae from the North East Atlantic coast of France was tested for their in vitro anti-algal activity against the growth of 12 strains of benthic and aggregating microalgae (Amphora coeffeaformis, Chlorococcum submarinum, Cylindrotheca closterium, Dunaliella tertiolecta, Micromonas pusilla, Phaeodactylum tricornutum, Porphyridium cruentum, Pyramimonas amylifera, Rhodella maculata, Rhodosorus marinus, Tetraselmis levis and Tetraselmis sp.) and against the adhesion of the spores of two species of macroalgae (Enteromorpha intestinalis and Ulva lactuca) and the zygotes of Sargassum muticum. The organisms selected are representative of the algal fouling community. 


\section{Materials and methods}

\subsection{Preparation of algal extracts}

Thirty marine algal species were collected in April 1998 from the East coast of France (Concarneau bay, Brittany, $47^{\circ} 52 \mathrm{~N}-3^{\circ} 55 \mathrm{~W}$ ) these included : (1) Enteromorpha intestinalis (Agardh), (2) Ulva lactuca (Agardh) (Ulvalceae), (3) Cladophora rupestris (Kützing) (Cladophoraceae), (4) Ascophyllum nodosum (Le Jolis), (5) Fucus serratus (Linneaeus), (6) F. spiralis (Linneaeus), (7) F. vesiculosus (Linneaeus), (8) Himanthalia elongata (Gray), (9) Pelvetia canaliculata (Decaisne and Thuret), (10) Sargassum muticum (Fensholt) (Fucaceae), (11) Ectocarpus siliquilosus (Lyngbye) (Ectocarpaceae), (12) Alaria esculenta (Gréville), (13) Chorda filum (Stackhouse), (14) Laminaria digitata (Lamouroux), (15) L. ochroleuca (La Pylaie), (16) Saccorhiza polyschides (Batters) (Laminariaceae), (17) Chondrus crispus (Stackhouse), (18) Gigartina stellata (Batters) (Gigartinaceae), (19) Gelidium latifolium (Bornet and Thuret) (Gelidiaceae), (20) Palmaria palmata (Küntze) (Palmariaceae), (21) Dilsea carnosa (Küntze) (Cryptonemiaceae), (22) Bornetia secundiflora (Thuret), (23) Ceramium rubrum (Hudson), (24) Cryptopleura ramosa (Hudson), (25) Delessaria sanguinea (Lamouroux), (26) Griffthsia floculosa (Bettenberg), (27) Halurus equisetifolius (Kützing), (28) Laurencia pinnatifida (Lamouroux), (29) Plumaria elegans (Schmitz) and (30) Polysiphonia lanosa (Tandy) (Ceramiaceae).

After collection, the samples were rinsed with sterile seawater to remove associated debris. Epiphytes were removed of the algae. The cleaned material was then surface dried by pressing it briefly between sheets of paper towelling and air dried in the shade at $30^{\circ} \mathrm{C}$ during 24 hours. The surface microflora was removed by washing the algal samples for ten minutes with $30 \%$ ethanol (Hellio et al., 2000a).

One part of the dried algae was suspended by stirring in distilled water (50 g. $\mathrm{L}^{-1}$ of dried weight) with an Ultra-turrax (2 hours) at $4^{\circ} \mathrm{C}$. After centrifugation $\left(30 \mathrm{~min}, 3000 \mathrm{~g}, 4^{\circ} \mathrm{C}\right.$ ) and filtration (Whatman cat $\mathrm{n}^{\circ}$ 1822 047), the supernatant was lyophilised and we obtained then the aqueous extract (Extract $A$ ).

For organic extracts, the dried algae were suspended by stirring in ethanol $95^{\circ}$ ( $200 \mathrm{~g}$ in $300 \mathrm{~mL}$ ) with an Ultra-turrax ( 2 hours) at $4^{\circ} \mathrm{C}$. After centrifugation $\left(30 \mathrm{~min}, 3000 \mathrm{~g}, 4^{\circ} \mathrm{C}\right.$ ), the resultant pellet was reextracted five times in the same way. The alcoholic extracts were combined and evaporated under vacuum at low temperature $\left(<40^{\circ} \mathrm{C}\right)$. Distilled water $(100 \mathrm{~mL})$ was then added and partitioned with methylene chloride $(4 \times 100 \mathrm{~mL})$. The aqueous phases were collected, lyophilised, re-suspended in absolute ethanol $(100 \mathrm{~mL})$, filtered and concentrated under vacuum at low temperature (Extract B). The organic phases were collected, dried during 24 hours under $\mathrm{Na}_{2} \mathrm{SO}_{4}$, filtered and concentrated under vacuum at low temperature (Extract C). Theses three phases were stored at $-40^{\circ} \mathrm{C}$ before use (Hellio et al., 2000a). The yield of each extraction for each extracts are shown in Table 1.

\subsection{Controls}

In all our different assays, we have also studied the activities of two well-known antifouling compounds currently used nowadays: half bis (tributyltin)oxide (TBTO) and cupric sulphate $\left(\mathrm{CuSO}_{4}\right)$. They were considered as positive controls. Moreover, negative controls were also performed using the extraction solvents (ethanol and dichloromethane).

\subsection{Microalgae}

\subsubsection{Strains}

Microalgae strains were obtained directly from the Culture Collection of Algae of the University of Caen (Dr. Benoît Veron, Laboratoire de Biologie et Biotechnologies Marines, Université de Caen BasseNormandie, Esplanade de la Paix, BP 5186, 14032 Caen Cedex, France) these include 4 strains (P1 to P4) of Prasinophyceae: Tetraselmis sp. (PRA3), Tetraselmis levis (PRA5) Micromonas pusilla (PRA11) and Pyramimonas amylifera (PRA10); 3 strains (P5 to P7) of Rhodophyceae: Rhodosorus marinus (RHO1), Porphyridium purpureum (RHO2) and Rhodella maculata (RHO3) ; 2 strains (P8 to P9) of Chlorophyceae: Dunaliella tertiolecta (CHL-14) and Chlorococcum submarinum (C-3); and 3 strains (P10 to P12) of Diatomophyceae Cylindrotheca closterium (DIA6), Phaeodactylum tricornutum (DIA7) and Amphora coffeaformis (AC-2078). 


\subsubsection{Culture}

Microalgae were maintained in $100 \mathrm{~mL}$ Erlenmeyer flasks under continuous illumination $\left(150 \mu \mathrm{mol}^{\mathrm{m}} \mathrm{m}^{-}\right.$ ${ }^{2} . s^{-1}$ white fluorescent lamps) at $18^{\circ} \mathrm{C}$ in Guillard's $F_{2}$ medium (Hellio et al., 2001b) excepted for M. pusilla, P. amylifera, R. maculata, D. tertiolecta, C. submarinum which were grown in $\mathrm{F}_{2}$-Si medium (Guillard \& Ryther, 1962). Culture media were all autoclaved $\left(120^{\circ} \mathrm{C}, 20 \mathrm{~min}\right.$.), inoculated under aseptic conditions (Hellio \& Le Gal, 1999) and were checked periodically for bacterial contamination (Hellio \& Le Gal, 1998).

\subsubsection{Screening of activity against the growth of microalgae}

All the following experiments were carried out in triplicate as previously explained in Hellio et al., 2001b. Fifteen $\mathrm{mL}$ aliquots of Guillard's $\mathrm{F}_{2}$ medium were introduced into sterile conical flasks and inoculated with $5.10^{5}$ cells. $\mathrm{mL}^{-1}$ of cultivated microalgae in exponential growth phase. Algal extract was then introduced in the flask leading to a final concentration of $300 \mu \mathrm{g}$ of extract per $\mathrm{mL}$ of culture. The flasks were then incubated at $18^{\circ} \mathrm{C}$ with a 12 hours light $\left(150 \mu \mathrm{mol} . \mathrm{m}^{-2} . \mathrm{s}^{-1}\right.$ white fluorescent lamps) and 12 hours dark cycle (Gotschalk \& Allredge, 1989). Two series of conical flasks containing either TBTO (1 $\left.\mu \mathrm{g} \cdot \mathrm{mL}^{-1}\right)$ or $\mathrm{CuSO}_{4}\left(10 \mu \mathrm{g} \cdot \mathrm{mL}^{-1}\right)$ were set up as positive controls. A standard, containing no biocides and no algal extract, was set up as a standard. Cell growth was estimated daily, over 5 days, by direct counting of the cells in a Malassez haematocytometer (Hellio and Le Gal, 1998).

For the most active extract, complementary assays were carried out in order to determine the range of activity : algal extracts were added to microalgal culture $\left(5.10^{5}\right.$ cells.mL $\left.{ }^{-1}\right)$ but here in various concentrations $\left(50,100,150,200,250\right.$ and $\left.300 \mu \mathrm{g} \cdot \mathrm{mL}^{-1}\right)$. All the microalgal strains were studied excepted Rhodosorus marinus (P5) and Dunaliella tertiolecta (P8). After 3 days of incubation, the number of cells was estimated by direct counting of the cells in a Malassez haematocytometer and the lowest extract concentration leading to total absence of cellular growth was recorded. In order to determine whether these extracts kill algae or just inhibit their growth, complementary experiments were carried out. Flasks containing $5.10^{5}$ cells. $\mathrm{mL}^{-1}$ were incubated with extract concentrations which stop the microalgal growth as previously determined, after 4 days incubation, the cells were rinsed and maintained in plain medium for a further 7 days and the cell number was assessed daily.

\subsection{Macroalgae}

The release and the collections of spores of Enteromorpha intestinalis \& Ulva lactuca and zygotes of Sargassum muticum were performed as previously explained in Hellio et al., 2001b. For the screening of activity on macroalgal spores and zygotes, plastic Petri dishes (35 $\mathrm{mm}$ in diameter) were used throughout the experiment as the substrate for settlement of spores (Hattori \& Shizuri, 1996). Test samples of algal extracts ( $300 \mu \mathrm{g} / \mathrm{ml}$ in final concentration) were dissolved in methanol and spread on the inner surface of a Petri dish and dried at room temperature. Each Petri dish containing $5 \mathrm{~mL}$ of Guillard's $\mathrm{F}_{2}$ medium was inoculated with approximately 3000 spores. Dishes were placed in the dark for $2 \mathrm{~h}$ to allow for even settlement of gametes. Two series of dishes with TBTO $1 \mu \mathrm{g} \cdot \mathrm{mL}^{-1}$ and $\mathrm{CuSO}_{4} 10 \mu \mathrm{g} \cdot \mathrm{mL}^{-1}$ were set up as positive antifouling controls. A standard, containing no biocides and no algal extract, was set up as a standard.

After incubation for 5 days at $20^{\circ} \mathrm{C}$ with 24 hours light $\left(150 \mu \mathrm{mol} \cdot \mathrm{m}^{-2} \cdot \mathrm{s}^{-1}\right.$ white fluorescent lamps), the germinated spores, ungerminated spores and unattached spores were counted on $1 \mathrm{~cm}^{2}$ areas of each Petri dish using an inverted binocular microscope. The germination and attachment rates were calculated (Hattori \& Shizuri, 1996). All experiments were replicated 3 times.

\subsection{Toxicity tests on larval oyster (Crassostrea gigas) and larval sea urchin (Echinus esculentus)}

Toxicity tests were conducted as previously described in Hellio et al. (2000 b). In order to determine the toxicity of the algal extract on the larval development of oysters and sea urchins, larvae were 
incubated with 6 different concentrations of algal extracts : 10, 50, 125, 250, 500, $1000 \mu \mathrm{g} \cdot \mathrm{L}^{-1}$. TBTO and $\mathrm{CuSO}_{4}\left(1,1025,50,75,100 \mu \mathrm{g} \cdot \mathrm{mL}^{-1}\right)$ were used as positive controls. Five replicates were used in order to reduce the effect of the natural variability between individuals. Results are expressed as the average of the replicate results. A population control comprised larvae reared in seawater. After 24 hours at $24^{\circ} \mathrm{C}$, larvae reached the $\mathrm{D}$ stage, (confirmed by microscopic observation). Larval development was then stopped by addition of $100 \mu \mathrm{L}$ of formol to the culture medium. The $\mathrm{CL}_{50}$ have been assed by using a loglogistic model (Kooijamn, 1981). The model has been fitted to the experimental data with the help of a non-linear regression program (SGPLUS vers2, Manugistics, Inc.). 


\section{Results}

\subsection{Anti-microalgal activity}

The effects of algal extracts on the growth of microalgae are shown in Tables 2, 3 and 4 respectively for aqueous (A), ethanol (B) and dichloromethane (C) fractions. None inhibition activitiy was observed with the two negative controls (ethanol and dichloromethane). After 5 days of incubation all the extracts tested were found to be active. Indeed, each of them was able to inhibit the growth of at least one microalga. For some of them, the level of inhibition was similar to those obtained with $10 \mu \mathrm{g} \cdot \mathrm{mL}^{-1}$ of $\mathrm{CuSO}_{4}$ or $1 \mu \mathrm{g} \cdot \mathrm{mL}^{-1} \mathrm{~L}$ of TBTO.

For all the macroalgal extracts studied and whatever the extraction procedure used (A, B or C) only two macroalgae namely $S$. muticum and $L$. pinnatifida were found active against the different microalgae. In addition, four extracts (9A, 17B, 30B and 30C) also appeared effective against all the phytoplanktonic strains studied.

One extract (11C) affected all except one microalgae (P6).

Two extracts ( $1 C$ and $3 A$ ) inhibited significantly the growth of all the representatives of 3 of the 4 classes of phytoplanktonic classes (Rhodophyceae, Chlorophyceae and Diatomophyceae)

Six extracts appeared to be effective against the development of at least 2 classes of plankton: 1B, 7B, 7C and 24A (against Rhodophyceae and Diatomophyceae), 18B \& 27B (against Chlorophyceae and Diatomophyceae).

Eighteen extracts were found active against at least one phytoplanktonic class: $4 \mathrm{~B}$ against Prasinophyceae ; 26B, 20C and 26C against Chlorophyceae 2A, 4A, 7A, 23A, 30A, 2B, 3B, 8B, 23B, 24B, 2C, 9C, 15C and 29C against Diatomophyceae.

Additional assays were carried out for the most active extracts (i.e. those which were able to reduce algal development by at least $60 \%$ ) in order to determine which concentration could lead to totally stop the development of the algal populations. The quantities required to inhibit fully phytoplankton proliferation ranged between 150 to over $300 \mu \mathrm{g} \cdot \mathrm{mL}^{-1}$ depending on the nature of the extract and the strain studied (Table 5). At $150 \mu \mathrm{g} \cdot \mathrm{mL}^{-1}$, twelve extracts were found able to stop the proliferation of at least one microalgal strain.

Among the microalgae studied, some appeared more sensitive to our algal extracts namely $R$. maculata (P7) and A. coffeaformis (P12) while others such as P. amylifera (P4) and P. purpureum (P6) were found more resistant (at $150 \mu \mathrm{g} \cdot \mathrm{mL}^{-1}$ none extracts were found able to inhibit fully the development of the population).

Further experiments were conducted to determine whether the toxic effects of active extracts on strains of microalgae were reversible. After pre-incubation for 4 days in the presence of algal extracts, the cells were rinsed and inoculated into fresh medium. After 7 days, in addition to $\mathrm{CuSO}_{4}$ and TBTO, two extracts (11C and 20C) were found to be algicidal at $150 \mu \mathrm{g} \cdot \mathrm{mL}^{-1}$ in the sense that phytoplanktonic growth was less than $10 \%$ (Table 6). For all others extracts, removal lead to a recovery of phytoplankton growth and growth rates between $380 \%$ and $500 \%$ were observed corresponding to normal values.

\subsection{Anti-macroalgae activity}

The effects of algal extracts on the rates of attachment and germination of spores and zygotes are shown on Tables 7, 8 and 9 respectively for aqueous (A), ethanol (B) and dichloromethane (C) extracts. No inhibition activity was observed with the negative controls (ethanol and dichloromethane). After 5 days of incubation, $37 \%$ of the extracts (34/90) were found to be inactive. Among them, all the extracts (A, B and C) from A. esculenta (12), B. secundiflora (22), D. sanguinea (25), G. floculosa (26), $H$. equisetifolius (27) and $P$. elegans (29) failed to inhibit either attachment or germination of macroalgal spores. Where extracts were active, they were generally more effective at inhibiting attachment rather than germination. Whatever the extraction procedures used (A, B or C), five algae S. muticum (10), L. ochroleuca (15), C. 
rubrum (23), L. pinnatifida (28) and $P$. lanosa (30) were found able to inhibit the attachment and the germination of all the spores studied here. Among the active extracts, eight (10A, 17A, 10B, 15B, 30B, $10 \mathrm{C}, 21 \mathrm{C}$, and $30 \mathrm{C}$ ) showed inhibition levels equivalent to those obtained for $\mathrm{CuSO}_{4}$ or TBTO. Ten extracts were only able to inhibit the development of the spores of two of the three macroalgae studied: 4B, 2C, 17C and 24C inactive against S. muticum ; 9A and 7C inactive against $E$. intestinalis; 4A, 7A, 11A and $11 \mathrm{~B}$ inactive against $U$. lactuca. In addition, three algal extracts inhibited only one type of spores: $18 \mathrm{~B}$ and $20 \mathrm{C}$ against $S$. muticum and $19 \mathrm{C}$ against $U$. lactuca.

\subsection{Toxicity testing on oyster (Crassostrea gigas) and sea urchin (Echinus esculentus)larvae}

Toxicity tests against non-target species were conducted and results are shown Table 10. TBTO and $\mathrm{CuSO}_{4}$, used as positive controls, were found to be highly toxic for the larvae studied and no viable larvae were detected in concentrations of $50 \mu \mathrm{g} \cdot \mathrm{mL}^{-1}$ or above.

On the basis of their toxicity, the extracts can be divided into 3 groups:

- The first one included highly toxic extracts against both oyster and sea urchin larvae $(1 \mathrm{~A}, 2 \mathrm{~B}, 2 \mathrm{C}$, 9A, 11B, 11C, 18B, 21C and 26B). The most toxic extracts were 2C, 11B, 11C \& 18B.

- The second group included extracts mainly toxic towards oysters: $2 \mathrm{~A}, 10 \mathrm{~A}, 11 \mathrm{~A} \& 21 \mathrm{~B}$. The more toxic is $11 \mathrm{~A}$ that lead to $\mathrm{CL}_{50}$ of $7 \mu \mathrm{g} / \mathrm{mL}$.

- Finally, the more numerous one which contains the less toxic extracts even against oyster or urchin larvae with $\mathrm{CL}_{50}$ values superior to $800 \mu \mathrm{g} / \mathrm{mL}$. 


\section{Discussion}

Allelochemistry refers to the effect of an organic compound, produced and released from one organism, on another organism. The effect can be on the growth, health, or population biology of the receptor organism with the exception of substances used as food (Harlin, 1996). Many allelopathic phenomena have been found in terrestrial plants. However, little information is available on allelopathic relationships in aquatic environments. Nevertheless, at the present time it has become clear that allelopathy plays an important role in the succession of planktonic algae, the regulation of algal populations and invertebrate colonisation (Tanaka \& Asakawa, 1988; Harlin, 1996). It seems likely that algae are chemically protected and dependent on either surface-bound or continuously released soluble compounds to deter settling invertebrate larvae. Algal compounds can affect the development and grazing of some settling organism indicating the presence of antifouling mechanisms. Negative chemical cues may signal a range of potential mortality agents, including predators, dominant competitors or areas with potentially lethal levels of disturbance (Walters et al., 1995). The isolation of biogenic agents produced by several species of micro-, and macroalgae and marine invertebrates with antibacterial, antialgal, antiprotozoan and antimacrofouling properties may be the most promising and effective method for the prevention of biofouling and the development of new antifouling paints.

In this study, a series of aqueous, ethanol and dichloromethane extracts of 30 marine algae was tested for their in vitro antialgal activity against the growth of 12 strains of aggregating microalgae and against the adhesion of the spores and zygotes of three species of macroalgae. As the goal of this study is to find new antifouling products to replace the more environmentally damaging toxins in current use, in particular against non-target species, 13 extracts among the 90 tested appeared toxic and have to be eliminated. Regarding to their activity, these toxic algal extracts can be divided in 2 groups. One group which contained products able to inhibit the development of all the spores of the macroalgae studied ( $E$. intestinalis $A, U$. lactuca A, S. muticum A \& D. carnosa C) ; the aqueous extract of S. muticum appeared also active against microalgal growth). In the second group we can classified the extracts that were found essentially active against several microalgae and at the opposite rather inactive against macroalgae $(U$. lactuca B \& C ; P. canaliculata A ; E. siliquosus A, B \& C ; G. stellata B ; D. carnosa B ; G. floculosa B). All the extracts of $U$. lactuca and $E$. siliquosus appeared toxic for both kind of organisms. Regarding to the toxicity, it is of interest to notice that oyster's larvae were found to be more sensitive (up to 25 more) that the sea urchin's ones. So, some fractions (U. lactuca A ; E. siliquosus A ; D. carnosa B and S. muticum A) appeared non-toxic against the larvae of sea urchin but killed those of oysters.

The none toxic algal extracts can be divided in five groups :

- The first one contains 41 extracts (46\% of the extracts studied here) showing only small activities against the growth of microalgae and no activity on the germination and fixation rates of macroalgae. We have so concluded that all of them present little interest for isolating active compounds against biofouling. Among those inactive extracts, the following species $F$. serratus, $F$. spiralis, , A. esculenta, C. Filum, L. digitata, S. polyschides, B. secundiflora, D. sanguinea, $H$. equisetifolius and $P$. elegans can be distinguished because none of their extracts appeared active. In addition, the following fractions can be added to this group: $H$ elongata (B \& $C$ ), G. stellata (A \& C), G. latifolium (A \& B), P. palmata (A \& B) ; D. carnosa (A), and G. floculosa (A\&C).

- The second group contains the most promising extracts because they exhibit high levels of activity in all the tests excepting the toxicity one. These extracts are namely the ethanol and dichloromethane fraction of S. muticum and P. lanosa. In previous studies (Hellio et al. 2000a ; Hellio et al., 2000b ; Hellio et al., 2001), these extracts were tested for their antifouling activities against other colonizers (bacteria, fungi and mussel). They have also been previously described as non-toxic towards lysosomal and mitochondrial activities (Hellio et al., 2001). So, those 4 extracts appeared able to inhibit the development of many biofoulers without any toxicity. Since any antifouling coating must be efficient against a large range of fouling organisms actually occurring in the field, such broad spectrum activities is important (De Nys et al., 1995).

- The third group of extracts consisted of extracts showing high level of activities against all the microalgae and lower effects on the germination and fixation rates of macroalgae. These extracts are the ethanolic fraction of $C$. crispus and the three fractions of $L$. pinnatifida. Such inhibitory activities are very promising, especially inhibitory effect towards diatoms which represented the 
principal share of biomass of microfouling organisms notably the genus Amphora which is generally accepted as being the most common of these (Jackson, 1991). Moreover, previous studies have shown that marine fouling diatoms are very commonly found on antifouling paints and are extremely tolerant to both copper and tributyltin (Robinson 1987a,b ; Evans, 1990). So, the inhibitory levels on microalgae obtained for this group appeared promising in the goal of an industrial application. Furthermore, our experiments revealed that very few inhibitors of microalgae detected here were lethal (Table 5). In previous works (Sawant and Wagh, 1994 ; Sawant and Carg, 1995), similar observations had lead the authors to conclude that the lag phase of microalgal growth was prolonged when active extracts were added and so the algal cells were still alive, although unable to grow. The authors suspected that the extracts might have interfered with any one of the enzyme activities of the diatom, which may have results in the inhibition of growth. While not unexpected, the variation in the effects of alga extracts suggest that they are not simply functioning as broad-spectrum toxins against marine organisms. Rather, they appear to have specific activities against one or several organisms. Indeed, such extracts were previously tested against micro- and macro-biofoulers (Hellio et al. 2000a ; Hellio et al., 2000b ; Hellio et al., 2001). They were only found active towards microorganisms (marine and terrestrial bacteria and marine fungi) but not inhibitory effects were noticed on the blue mussel Mytilus edulis. Moreover, they were found non-toxic on the mitochondrial and lysosomal activities of mouse fibroblasts. So, these results are also very promising as non-toxic or low toxicity deterrence of fouling is the goal of new antifouling technologies.

- The fourth group contains 4 extracts showing activities mainly towards macroalgae even we can observe few activities against microalgae. These extracts are $P$. canaliculata (B \& $C$ ), $L$. ochroleuca (B) and C. crispus (A). Marine natural products or extracts with activities against spores of macroalgae have been isolated from a wide number of marine prokaryotes and eucaryotes (Davis et al., 1991) including gorgorians (Rittschof et al., 1986 ; Keifer et al., 1986), sponges (Davis and Wright, 1990), marine bacteria (Holmström et al. , 1992) and macroalgae (De Nys et al., 1995). So, active metabolites have been isolated from Dilsea pulchra and were found to be able to strongly inhibit the germination of $U$. lactuca gametes at $25 \mathrm{ng} / \mathrm{cm}^{2}$ (De Nys et al., 1995). Such interactions among marine algae through the excretion of growth-inhibiting substances, even released by the algae itself, has been suggested to play an important role in ecology (Harlin 1996). Indeed, allelochemicals are known to regulate and control community structure and determine succession. So, for example, spores of $L$. saccharina and $F$. vesiculosus were shown to be extremely sensitive to chemicals whereas adult were not (Harlin, 1996). In our study, the majority of the extracts of Sargassum muticum, Enteromorpha intestinalis and Ulva lactuca inhibited respectively the attachment and germination rates of their own spores. This sensitivity of sexual cells makes algae useful for the bioassay of toxicants and allelopathy.

- Finally, the last group contains the 25 remaining extracts that exhibit activities towards only one or two groups of microalgae. These extracts can be of interest if we are looking for the inhibition of a especially taxonomic group of microalgae but in the view of an antifouling product with a broad spectrum of activities these extracts do not appear very useful. 


\section{Conclusion}

These results suggest that among the different marine macroalgae studied here, some appeared to be able to produce effective antialgal compounds non-toxic to invertebrate larvae. Our screening procedure reveals that particular metabolites can be isolated for limiting the development of fouling organisms (such as microalgae and/or macroalgae) with minimal effects on non-target organisms. From commercial perspectives of developing novel antifouling coatings, such metabolites will have 3 useful characteristics: (1) a high activity against a range of fouling organisms; (2) an activity due to chemical signalling rather than simple toxicity; (3) an activity spectrum more or less extended which can be useful for specific situations. Moreover, macroalgae present the advantage to be suitable for mass culture what is limiting the problem of accessibility of such bioactive compounds. Among all our extracts, at least 12 appeared of great interest due to their specific inhibiting activities and their non-toxicity against invertebrate larvae. The extraction and purification procedures of the active metabolites responsible for these activities are currently in progress.

\section{Acknowledgements}

Financial support by the European Community and by the Brittany council (France) is gratefully acknowledged. Special thanks are given to Pr. B. Leadbeater (University of Birmingham, UK) for his precious help in the preparation of this manuscript. 


\section{References}

Abarzua S, Jakubowski S (1995) Biotechnological investigation for the prevention of biofouling. I. Biological and biochemical principles for the prevention of biofouling. Mar Ecol Prog Ser 123 : 301-312

Alzieu C, Thibaud Y, Heral M, Boutier B (1980) Evaluation des risques dus à l'emploi des peintures antisalissures dans les zones conchilicoles. Rev Trav Inst Peches Marit 44 : 301-348

Bryan G, Gibbs P, Hummerstone L, Burt G (1986) The decline of gasteropod Nucella lapillus around south-west England : Evidence for the effect of tributyltin from antifouling paints. J Mar Biol Assoc UK 66 : 611-640

Davis A, Wright A (1990) Inhibition of larval settlement by natural products from the ascidian Eudistoma olivaceum. J Chem Ecol 16 : 1349-1357

Davis A, Butler A, Van Altena I (1991) Settlement behaviour of ascidian larvae : preliminary evidence for inhibition by sponge allochemicals. Mar Ecol Prog Ser 72 : 117-123

De Nys R, Steinberg P, Willemsen P, Dworjanyn S, Gabelish C, King R (1995) Broad spectrum effects of secondary metabolites from the red algae Delisea pulchra in antifouling assays. Biofouling 8 : 259-271

Evans L (1990) Underwater foul play. Biol Sci Rep 2 : 35-38

Fletcher R (1980) Studies of the recently introduced brown alga Sargassum muticum (yendo) Fensholt. Bot Mar 23 : 425-432

Fletcher R (1989) A bioassay technique using the marine fouling green alga Enteromorpha. Inter Biodeter Biodegrad 25 : 407-422

Gotschalk C, Alldredge A (1989) Enhanced primary production and nutrient regeneration within aggregated marine diatoms. Mar Biol 103 : 119-129

Guillard R, Ryther J (1962) Studies of marine planktonic diatoms. I. Cyclotella nana (Hustedt), and Detonula confervacea (Cleve). Can J Microbiol 8 : 229-239

Harlin M (1996) Allelochemistry in marine macroalgae. Crit Rev Toxicol 5(3) : 237-249

Hattori T, Shizuri Y (1996) A screening method for antifouling substances using spores of the fouling macroalga Ulva conglobata Kjel larvae and new antifouling technology. Biofouling 8 : 147-160

Hellio C, Le Gal Y (1998) Histidine utilization by the unicellular alga Dunaliella tertiolecta. Comp Biochem Physiol 119A : 753-758

Hellio C, Le Gal Y (1999) Histidase from the unicellular green alga Dunaliella tertiolecta : purification and partial characterization. Eur J Phycol 34 : 71-78

Hellio C, Bourgougnon N, Le Gal Y (2000a) Phenoloxidase (E.C. 1.14.18.1) from Mytilus edulis byssus gland : purification, partial characterization and application for screening products with potential antifouling activities. Biofouling $16: 235-244$

Hellio C, Bremer G, Pons AM, Le Gal Y, Bourgougnon N (2000b) Inhibition of the development of microorganisms (bacteria and fungi) by extracts of marine algae from Brittany (France). Appl Microb Biotech 54 (4) : 543-549 
Hellio C, De La Broise D, Dufosse L, Le Gal Y, Bourgougnon N (2001a) Inhibition of marine bacteria by extracts of macroalgae : potential use for environmentally friendly antifouling paints. Mar Environ Res 52 (3) : 231-247

Hellio C, Thomas-Guyon H, Culioli G, Poivetti L, Bourgougnon N, Le Gal Y (2001b) Marine antifoulants from Bifurcaria bifurcata (Phaeophyceae, Cystoseiraceae) and other brown macroalgae. Biofouling 17(3) : in press

Hölstrom C, Rittschof D, Kjelleberg S (1992) Inhibition of settlement by larvae of Balanus amphrite and Ciona intestinalis by a surface-colonizing marine bacterium. Appl Environ Microbiol 58 : 2111-2115

Hölstrom C, Kjelleberg S (1994) The effect of external biological factors on settlement of marine invertebrate larvae and new antifouling technology. Biofouling 8 : 147-160

Jackson S (1991) Microalgae : their status as fouling organisms. Oebalia 17 : 295-303.

Keifer P, Rinehart K, Hooper I (1986) Renillafoulins, antifouling diterpenes from the sea pansy Renilla reniformis (Octocorilla). J Org Chem 51 : 4450-4454

Kjelleberg S, Steinberg P (1994) Marine biofouling : problems and solution-executive summary. In Biofouling : Problems and solutions - Proc Int Workshop (Kjelleberg, S. Steinberg, P. D. editors), 32-38. UNSW, Sydney, Australia.

Kooijman S (1981) Parametric analysis of mortality rate in bioassays. Water Res 15 : 107-119

Miki W, Kon-ya K, Mizobuchi S (1996) Biofouling and marine biotechnology : new antifoulants from marine invertebrates. J Mar Biotechnol 4 : 117-120

Rittschof D, Maki J, Mitchell R, Costlow J (1986) Ion and neuropharmacological studies of barnacle settlement. Neth J Sea Res 20 : 269-275

Sawant S, Wagh A (1994) Studies on the antifouling properties of some natural products from Goa. In : Recent development in biofouling control. (Thompson M, Nagabbhushanam R, Sarojini R, Fingerman M, editors), 275-282, Oxford \& IBH Publ. Co., New Delhi.

Sawant S, Garg A (1995) Growth inhibition of fouling bacteria and diatoms by extract of terrestrial plant, Derris scandens (Dicotyledonae : leguminocae). Indian J Mar Sci 24 : 229-230

Tanaka N, Asakawa A (1988) Allelopathic effect of mucilage released from a brown alga Sargassum horneri on marine diatoms. Nippon Suisan Gakk 54 : 1711-1714

Todd J, Zimmerman R, Crews P, Randall S (1993) The antifouling activity of natural and synthetic phenolic acid sulfate esters. Phytochemistry 34 : 401-404

Vanelle L, Le Gal Y (1995) Marine antifoulants from North Atlantic algae and invertebrates. J Mar Biotechnol 3 : 161-163 
Table 1 : Extraction Yield. Yields are expressed as the weight of the extract obtained (in $\mathrm{g}$ ) for $100 \mathrm{~g}$ of dry algae

\begin{tabular}{lccc}
\hline & Aqueous extractn (A) & $\begin{array}{c}\text { Ethanolic extraction } \\
(\mathrm{B})\end{array}$ & \begin{tabular}{c} 
Dichloromethane extraction (C) \\
\hline E. intestinalis (1)
\end{tabular} \\
U. lactuca (2) & 38 & 27 & 31 \\
C. rupestris (3) & 35 & 25 & 26 \\
A. nodosum (4) & 31 & 21 & 26 \\
F. serratus (5) & 33 & 21 & 28 \\
F. spiralis (6) & 30 & 25 & 19 \\
F. vesiculosus (7) & 34 & 25 & 26 \\
H. elongata (8) & 36 & 24 & 28 \\
P. canaliculata (9) & 37 & 21 & 31 \\
S. muticum (10) & 31 & 26 & 29 \\
E. siliquosus (11) & 33 & 29 & 40 \\
A. esculenta (12) & 32 & 21 & 37 \\
C. filum (13) & 32 & 22 & 32 \\
L. digitata (14) & 34 & 23 & 32 \\
L. ochroleuca (15) & 35 & 25 & 29 \\
S. polyschides (16) & 29 & 27 & 18 \\
C. crispus (17) & 37 & 27 & 22 \\
G. stellata (18) & 35 & 29 & 29 \\
G. latifolium (19) & 36 & 21 & 33 \\
P. palmata (20) & 40 & 22 & 34 \\
D. carnosa (21) & 32 & 24 & 32 \\
B. secundiflora (22) & 30 & 25 & 36 \\
C. rubrum (23) & 28 & 25 & 37 \\
C. ramosa (24) & 31 & 27 & 31 \\
D. sanguinea (25) & 32 & 21 & 31 \\
G. floculosa (26) & 33 & 24 & 31 \\
H. equisetifolius (27) & 37 & 24 & 23 \\
L. pinnatifida (28) & 38 & 22 & \\
P. elegans (29) & 35 & 27 & 21 \\
P. lanosa (30) & 36 & 22 & \\
\hline
\end{tabular}


Table 2 : Effect of aqueous (A) extracts $\left(300 \mu \mathrm{g} \cdot \mathrm{mL}^{-1}\right)$ and TBTO $\left(1 \mu \mathrm{g} \cdot \mathrm{mL}^{-1}\right)$ and $\mathrm{CuSO}_{4}\left(10 \mu \mathrm{g} \cdot \mathrm{mL}^{-1}\right)$ on the growth of microalgae after 5 days of incubation. Results are expressed as the percentage inhibition of the growth of each strain (compared with untreated control).

\begin{tabular}{|c|c|c|c|c|c|c|c|c|c|c|c|c|}
\hline & P1 & $\mathrm{P} 2$ & P3 & $\mathrm{P} 4$ & P5 & P6 & P7 & P8 & P9 & P10 & P11 & P12 \\
\hline TBTO & 79 & 83 & 88 & 93 & 71 & 86 & 89 & 91 & 76 & 87 & 90 & 88 \\
\hline $\mathrm{CuSO}_{4}$ & 76 & 81 & 77 & 81 & 82 & 76 & 74 & 71 & 73 & 88 & 81 & 76 \\
\hline E. intestinalis (1) & 4 & - & 8 & - & - & 8 & - & - & 5 & 45 & - & - \\
\hline U. lactuca (2) & - & - & 15 & - & 22 & - & 13 & - & - & 25 & 27 & 21 \\
\hline C. rupestris (3) & - & - & - & 42 & 53 & 55 & 33 & 44 & 46 & 55 & 52 & 29 \\
\hline A. nodosum (4) & - & - & 12 & - & 15 & - & 8 & - & - & 5 & 6 & 32 \\
\hline F. serratus (5) & - & - & 5 & 9 & 11 & - & - & - & 3 & - & - & - \\
\hline F. spiralis (6) & - & 4 & - & - & - & - & 5 & - & 9 & - & - & - \\
\hline F. vesiculosus (7) & - & 6 & - & - & 33 & - & 11 & - & - & 31 & 12 & 13 \\
\hline H. elongata (8) & - & - & 13 & - & - & - & 11 & - & 9 & - & - & - \\
\hline P. canaliculata (9) & 76 & 53 & 46 & 37 & 38 & 41 & 8 & 2 & 12 & 46 & 32 & 11 \\
\hline S. muticum (10) & 33 & 47 & 81 & 34 & 45 & 39 & 44 & 38 & 51 & 37 & 33 & 32 \\
\hline E. siliquosus (11) & 4 & - & - & - & - & - & - & - & 6 & - & 31 & - \\
\hline A. esculenta (12) & - & 5 & - & - & - & 3 & - & - & - & - & - & - \\
\hline C. filum (13) & - & - & 7 & 11 & - & 9 & - & - & - & 2 & - & - \\
\hline L. digitata (14) & 8 & - & - & 5 & - & - & - & - & - & - & - & - \\
\hline L. ochroleuca (15) & - & - & - & - & - & 11 & - & - & - & 25 & 33 & - \\
\hline S. polyschides (16) & - & - & 2 & - & - & - & 8 & - & - & - & - & - \\
\hline C. crispus (17) & - & 5 & - & - & 35 & - & 14 & - & - & 11 & 32 & - \\
\hline G. stellata (18) & 11 & - & - & 11 & 13 & - & - & - & - & - & 9 & - \\
\hline G. Iatifolium (19) & 5 & - & 14 & 17 & 11 & - & - & - & - & - & - & - \\
\hline P. palmata (20) & - & 4 & - & - & 11 & - & - & - & - & 9 & - & - \\
\hline D. carnosa (21) & - & - & 6 & - & - & - & 11 & - & 13 & - & - & - \\
\hline B. secundiflora (22) & - & 9 & - & - & 11 & - & - & - & - & 11 & 8 & - \\
\hline C. rubrum (23) & - & - & - & - & 2 & - & 16 & - & - & 12 & 11 & 41 \\
\hline C. ramosa (24) & - & 4 & - & - & 9 & 6 & 11 & - & - & 36 & 42 & 29 \\
\hline D. sanguinea (25) & - & 7 & - & - & 13 & 8 & 13 & - & - & - & 6 & - \\
\hline G. floculosa (26) & 7 & - & - & 21 & 14 & - & - & - & - & 11 & - & - \\
\hline H. equisetifolius (27) & - & 4 & - & - & - & - & 9 & - & 11 & - & - & - \\
\hline L. pinnatifida (28) & 44 & 78 & 54 & 77 & 81 & 56 & 65 & 49 & 53 & 33 & 18 & 87 \\
\hline P. elegans (29) & 22 & - & - & 12 & 11 & - & - & - & - & - & - & - \\
\hline P. lanosa (30) & - & - & - & 11 & 43 & - & - & - & 3 & 13 & 40 & 45 \\
\hline
\end{tabular}

TBTO and $\mathrm{CuSO}_{4}$ are used as positive antifouling controls.

- : no inhibition

P1 : Tetraselmis sp., P2 : Tetraselmis levis, P3 : Micromonas pusilla, P4 : Pyramimonas amylifera, P5: Rhodosorus marinus, P6 : Porphyridium purpureum, P7 : Rhodella maculata, P8 : Dunaliella tertiolecta, P9 : Chlorococcum submarinum, P10 : Cylindrotheca closterium,P11 : Phaeodactylum tricornutum, P12 : Amphora coffeaformis. 
Table 3 : Effect of ethanolic (B) extracts $\left(300 \mu \mathrm{g} \cdot \mathrm{mL}^{-1}\right)$ on the growth of microalgae after 5 days of incubation. Results are expressed as the percentage of inhibition of the cells growth (compared with untreated control).

\begin{tabular}{|c|c|c|c|c|c|c|c|c|c|c|c|c|}
\hline & $\mathrm{P} 1$ & $\mathrm{P} 2$ & P3 & $\mathrm{P} 4$ & $\mathrm{P} 5$ & P6 & P7 & P8 & P9 & P10 & P11 & $\mathrm{P} 12$ \\
\hline E. intestinalis (1) & - & - & 12 & 21 & 18 & 33 & 7 & - & 3 & 21 & 19 & 41 \\
\hline U. lactuca (2) & 23 & - & 17 & 5 & 6 & - & 6 & - & - & 21 & 24 & 12 \\
\hline C. rupestris (3) & - & 25 & - & 11 & 17 & - & 23 & - & 12 & 8 & 14 & 21 \\
\hline A. nodosum (4) & 41 & 71 & 53 & 28 & 14 & - & - & - & - & 4 & - & - \\
\hline F. serratus (5) & 6 & - & - & - & 12 & 14 & - & - & - & - & 5 & - \\
\hline F. spiralis (6) & 6 & - & - & - & 11 & - & - & - & - & 3 & - & - \\
\hline F. vesiculosus (7) & 12 & - & - & 14 & 25 & 26 & 3 & - & - & 11 & 24 & 17 \\
\hline H. elongata (8) & - & - & 4 & 9 & - & 12 & 3 & - & - & 2 & 13 & 12 \\
\hline P. canaliculata (9) & 87 & 56 & 76 & - & 8 & - & 6 & - & - & - & - & 3 \\
\hline S. muticum (10) & 87 & 76 & 81 & 79 & 56 & 54 & 40 & 66 & 71 & 43 & 81 & 51 \\
\hline E. siliquosus (11) & - & - & 1 & - & 5 & - & - & - & - & 4 & - & 9 \\
\hline A. esculenta (12) & - & - & - & 11 & 8 & - & - & - & - & - & - & 7 \\
\hline C. filum (13) & - & - & - & 5 & 9 & - & - & - & 6 & - & - & - \\
\hline L. digitata (14) & - & - & - & 10 & - & - & - & - & 7 & - & - & - \\
\hline L. ochroleuca (15) & 7 & - & 8 & - & 13 & - & - & - & - & 15 & - & 33 \\
\hline S. polyschides (16) & 6 & - & - & - & 5 & - & - & - & - & 11 & - & - \\
\hline C. crispus (17) & 37 & 76 & 58 & 79 & 56 & 58 & 51 & 75 & 56 & 37 & 39 & 29 \\
\hline G. stellata (18) & 78 & 58 & 85 & - & - & - & 89 & 85 & 83 & 88 & 91 & 92 \\
\hline G. Iatifolium (19) & 4 & - & - & 11 & 17 & 14 & - & - & - & 8 & 6 & - \\
\hline P. palmata (20) & - & - & 33 & 10 & - & - & - & - & - & - & - & - \\
\hline D. carnosa (21) & - & - & - & 87 & 79 & 85 & - & - & - & - & - & - \\
\hline B. secundiflora (22) & 7 & - & - & - & 9 & - & - & - & - & - & - & - \\
\hline C. rubrum (23) & 88 & 76 & 87 & - & 7 & - & - & - & - & 11 & 5 & 15 \\
\hline C. ramosa (24) & 5 & - & - & 7 & - & - & - & - & 6 & 11 & 6 & 12 \\
\hline D. sanguinea (25) & 5 & 14 & 19 & - & - & - & - & - & - & - & - & 7 \\
\hline G. floculosa (26) & 64 & 71 & 77 & - & - & - & 4 & 8 & 11 & - & 7 & - \\
\hline H. equisetifolius (27) & - & - & 13 & 4 & - & - & 78 & 83 & 55 & 43 & 76 & 85 \\
\hline L. pinnatifida (28) & 77 & 54 & 83 & 58 & 65 & 55 & 68 & 77 & 51 & 33 & 16 & 81 \\
\hline P. elegans (29) & 4 & 11 & - & - & 21 & 13 & 2 & 6 & - & - & - & - \\
\hline P. lanosa (30) & 87 & 54 & 77 & 71 & 55 & 49 & 76 & 81 & 95 & 88 & 41 & 85 \\
\hline
\end{tabular}

- : no inhibition

P1 : Tetraselmis sp., P2 : Tetraselmis levis, P3 : Micromonas pusilla, P4 : Pyramimonas amylifera, P5: Rhodosorus marinus, P6 : Porphyridium purpureum, P7 : Rhodella maculata, P8 : Dunaliella tertiolecta, P9 : Chlorococcum submarinum, P10 : Cylindrotheca closterium,P11 : Phaeodactylum tricornutum, P12 : Amphora coffeaformis. 
Table 4 : Effect of dichloromethane (C) extracts $\left(300 \mu \mathrm{g} \cdot \mathrm{mL}^{-1}\right)$ on the growth of microalgae after 5 days of incubation Results are expressed as the percentage of inhibition of the cells growth (compared with untreated control).

\begin{tabular}{|c|c|c|c|c|c|c|c|c|c|c|c|c|}
\hline & $\mathrm{P} 1$ & $\mathrm{P} 2$ & P3 & $\mathrm{P} 4$ & P5 & P6 & P7 & P8 & P9 & P10 & P11 & $\mathrm{P} 12$ \\
\hline E. intestinalis (1) & - & - & - & 51 & 46 & 39 & 38 & 43 & 11 & 8 & 40 & 37 \\
\hline U. lactuca (2) & - & - & 5 & - & 31 & - & - & - & - & 42 & 45 & 40 \\
\hline C. rupestris (3) & - & - & 11 & 3 & - & - & - & - & - & 17 & 14 & - \\
\hline A. nodosum (4) & 21 & - & - & 4 & 8 & - & - & - & - & 14 & 33 & - \\
\hline F. serratus (5) & 4 & - & - & - & - & 3 & 8 & - & 11 & - & - & - \\
\hline F. spiralis (6) & - & - & 7 & 8 & - & - & - & - & 4 & - & - & - \\
\hline F. vesiculosus (7) & - & 4 & - & - & 11 & 13 & 11 & - & - & 14 & 17 & 21 \\
\hline H. elongata (8) & - & - & - & 6 & - & - & - & - & - & - & - & - \\
\hline P. canaliculata (9) & 8 & - & - & - & - & 11 & - & - & - & 45 & 41 & 29 \\
\hline S. muticum (10) & 51 & 54 & 38 & 42 & 39 & 51 & 79 & 77 & 87 & 47 & 71 & 63 \\
\hline E. siliquosus (11) & 79 & 88 & 93 & 9 & 12 & - & 33 & 38 & 29 & 41 & 49 & 37 \\
\hline A. esculenta (12) & 5 & - & - & - & 3 & - & - & - & - & - & - & - \\
\hline C. filum (13) & 11 & 13 & - & 9 & - & 33 & - & - & - & - & 11 & - \\
\hline L. digitata (14) & - & 5 & 3 & - & - & - & - & - & - & - & - & - \\
\hline L. ochroleuca (15) & - & 9 & - & - & - & 13 & 17 & - & - & 12 & 22 & 19 \\
\hline S. polyschides (16) & - & - & - & 11 & 9 & 13 & - & - & 6 & - & - & 11 \\
\hline C. crispus (17) & - & - & 12 & - & - & - & - & - & 9 & 12 & - & 32 \\
\hline G. stellata (18) & - & - & 2 & - & - & - & 5 & - & 11 & - & 8 & - \\
\hline G. latifolium (19) & 4 & - & - & - & 14 & 21 & - & - & - & - & - & - \\
\hline P. palmata (20) & - & - & - & 4 & 9 & - & 88 & 93 & 91 & - & - & - \\
\hline D. carnosa (21) & - & - & - & 11 & 15 & 14 & - & - & - & - & - & 7 \\
\hline B. secundiflora (22) & - & - & 13 & 7 & - & - & - & - & 8 & - & - & - \\
\hline C. rubrum (23) & 88 & 83 & 91 & - & - & - & - & - & - & - & 6 & - \\
\hline C. ramosa (24) & 5 & 14 & - & 16 & - & - & - & - & 11 & 12 & 21 & - \\
\hline D. sanguinea (25) & 12 & - & - & - & 9 & - & - & - & - & - & - & 11 \\
\hline G. floculosa (26) & 3 & - & - & 11 & 19 & - & 4 & 7 & 8 & 12 & 2 & - \\
\hline H. equisetifolius (27) & 7 & - & - & 88 & 56 & 78 & - & - & - & 6 & - & - \\
\hline L. pinnatifida (28) & 41 & 38 & 35 & 56 & 63 & 55 & 78 & 51 & 26 & 37 & 29 & 62 \\
\hline P. elegans (29) & 7 & 2 & - & - & - & 3 & - & - & - & 5 & 8 & 11 \\
\hline P. lanosa (30) & 38 & 53 & 67 & 78 & 85 & 83 & 92 & 89 & 78 & 37 & 41 & 40 \\
\hline
\end{tabular}

- : no inhibition

P1: Tetraselmis sp., P2: Tetraselmis levis, P3: Micromonas pusilla, P4 : Pyramimonas amylifera, P5: Rhodosorus marinus, P6: Porphyridium purpureum, P7: Rhodella maculata, P8: Dunaliella tertiolecta, P9: Chlorococcum submarinum, P10 : Cylindrotheca closterium, P11 : Phaeodactylum tricornutum, P12 : Amphora coffeaformis. 
Table 5 : Concentration ( $\mu$ g. $\mathrm{mL}^{-1}$ ) leading to stop the cellular division after three days of incubation.

\begin{tabular}{|c|c|c|c|c|c|c|c|c|c|c|}
\hline & P1 & P2 & P3 & P4 & P6 & P7 & P9 & $\mathrm{P} 10$ & P11 & P12 \\
\hline A. nodosum B (4) & - & 250 & - & - & - & - & - & - & - & - \\
\hline P. canaliculata A (9) & 250 & - & - & - & - & - & - & - & - & - \\
\hline P. canaliculata B (9) & 150 & - & 250 & - & - & - & - & - & - & - \\
\hline S. muticum A (10) & - & - & 250 & - & - & - & - & - & - & - \\
\hline S. muticum B (10) & 300 & 300 & 250 & 250 & - & - & 300 & - & 150 & - \\
\hline S. muticum C (10) & - & - & - & - & - & 150 & 250 & - & 150 & 150 \\
\hline E. siliquosus C (11) & 150 & 150 & 150 & - & - & - & - & - & - & - \\
\hline C. crispus B (17) & - & 250 & - & 300 & - & - & - & - & - & - \\
\hline G. stellata B (18) & 250 & - & 250 & - & - & 150 & 150 & 250 & 250 & 250 \\
\hline P. palmata C (20) & - & - & - & - & - & 150 & 150 & - & - & - \\
\hline D. carnosa B (21) & - & - & - & 250 & 300 & - & - & - & - & - \\
\hline C. rubrum B (23) & 250 & 250 & 250 & - & - & - & - & - & - & - \\
\hline C. rubrum C (23) & 150 & 150 & 150 & - & - & - & - & - & - & - \\
\hline G. floculosa B (26) & 250 & 250 & 250 & - & - & - & - & - & - & - \\
\hline H. equisetifolius B (27) & - & - & - & - & - & 250 & - & - & 250 & 250 \\
\hline H. equisetifolius C (27) & - & - & 250 & - & - & - & - & - & - & - \\
\hline L. pinnatifida $\mathrm{A}(28)$ & - & 250 & - & 300 & - & 150 & - & - & - & 150 \\
\hline L. pinnatifida B (28) & 250 & - & 300 & - & - & 150 & - & - & - & 150 \\
\hline L. pinnatifida C (28) & - & - & - & - & - & 150 & - & - & - & 150 \\
\hline P. lanosa B (30) & 300 & - & 300 & 250 & - & 150 & 150 & 150 & - & 150 \\
\hline P. lanosa C (30) & - & - & 300 & 300 & 300 & 150 & 150 & - & - & 150 \\
\hline
\end{tabular}

-: >300 $\mu \mathrm{g} \cdot \mathrm{mL}^{-1}$

P1 : Tetraselmis sp., P2 : Tetraselmis levis, P3 : Micromonas pusilla, P4 : Pyramimonas amylifera, P6: Porphyridium purpureum, P7 : Rhodella maculata, P9 : Chlorococcum submarinum, P10 : Cylindrotheca closterium,P11 : Phaeodactylum tricornutum, P12 : Amphora coffeaformis. 
Table 6 : Physical conditions of the cells $\left(5.10^{5}\right.$ cell. $\left.\mathrm{mL}^{-1}\right)$ subjected to $150 \mu \mathrm{g} \cdot \mathrm{mL}^{-1}$ of the most active extract and to $\mathrm{CuSO}_{4}\left(10 \mu \mathrm{g} \cdot \mathrm{mL}^{-1}\right)$ and TBTO $\left(1 \mu \mathrm{g} \cdot \mathrm{mL}^{-1}\right)$ after 4 days pre-incubation and growth in a plain medium for 7 days. Results are expressed as the growth rate (in percentage) in comparison with the day of incubation.

\begin{tabular}{|c|c|c|c|c|c|c|c|c|c|c|}
\hline & P1 & P2 & P3 & P4 & P6 & P7 & P9 & P10 & P11 & P12 \\
\hline $\mathrm{CuSO}_{4}$ & 2 & 1 & 5 & 3 & 6 & 10 & 8 & 2 & 5 & 7 \\
\hline TВTO & 13 & 2 & 2 & 4 & 2 & 5 & 6 & 3 & 1 & 8 \\
\hline P. canaliculata B (9) & 378 & - & - & - & - & - & - & - & - & - \\
\hline S. muticum B (10) & - & - & - & - & - & - & - & - & 402 & - \\
\hline S. muticum C (10) & - & - & - & - & - & 423 & - & - & 376 & 477 \\
\hline E. siliquosus C (11) & 7 & 2 & 9 & - & - & - & - & - & - & - \\
\hline G. stellata B (18) & - & - & - & - & - & 391 & 412 & - & - & - \\
\hline P. palmata C (20) & - & - & - & - & - & 5 & 14 & - & - & - \\
\hline C. rubrum C (23) & 467 & 433 & 415 & - & - & - & - & - & - & - \\
\hline L. pinnatifida A (28) & - & - & - & - & 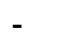 & 423 & - & - & - & 445 \\
\hline L. pinnatifida B (28) & - & - & - & - & - & 466 & - & - & - & 472 \\
\hline L. pinnatifida C (28) & - & - & - & - & - & 471 & - & - & - & 436 \\
\hline P. lanosa B (30) & - & - & - & - & - & 453 & 480 & 428 & - & 456 \\
\hline P. lanosa C (30) & - & - & - & - & - & 494 & 418 & - & - & 416 \\
\hline
\end{tabular}

- : non determined

P1 : Tetraselmis sp., P2 : Tetraselmis levis, P3 : Micromonas pusilla, P4 : Pyramimonas amylifera, P6: Porphyridium purpureum, P7 : Rhodella maculata, P9 : Chlorococcum submarinum, P10 : Cylindrotheca closterium, P11 : Phaeodactylum tricornutum, P12 : Amphora coffeaformis. 
Table 7 : Effect of aqueous (A) extracts $\left(300 \mu \mathrm{g} \cdot \mathrm{mL}^{-1}\right)$ on the attachment rate (AR) and of the germination rate (GR) on spores of macroalgae after 5 days of incubation. TBTO $1 \mu \mathrm{g} \cdot \mathrm{mL}^{-1}$ and $\mathrm{CuSO}_{4} 10 \mu \mathrm{g} \cdot \mathrm{mL}^{-1}$ are used as positive controls

\begin{tabular}{|c|c|c|c|c|c|c|}
\hline & \multicolumn{2}{|c|}{$\begin{array}{l}\text { Sargassum } \\
\text { muticum }\end{array}$} & \multicolumn{2}{|c|}{$\begin{array}{l}\text { Enteromorpha } \\
\text { intestinalis }\end{array}$} & \multicolumn{2}{|c|}{$\begin{array}{l}\text { Ulva } \\
\text { lactuca }\end{array}$} \\
\hline & AR & GR & AR & GR & AR & GR \\
\hline $\mathrm{CUSO}_{4}$ & 95 & 91 & 88 & 87 & 89 & 54 \\
\hline TВTO & 75 & 56 & 72 & 88 & 76 & 52 \\
\hline E. intestinalis (1) & 79 & 58 & 71 & 52 & 58 & 29 \\
\hline U. lactuca (2) & 88 & 57 & 79 & 45 & 51 & 27 \\
\hline C. rupestris (3) & 21 & 18 & 81 & 80 & 83 & 58 \\
\hline A. nodosum (4) & 71 & 68 & 11 & 10 & - & - \\
\hline F. serratus (5) & - & - & - & - & - & - \\
\hline F. spiralis (6) & - & - & - & - & - & - \\
\hline F. vesiculosus (7) & 33 & 26 & 70 & 52 & - & - \\
\hline H. elongata (8) & - & - & 11 & - & - & - \\
\hline P. canaliculata (9) & 9 & 6 & - & - & 81 & 79 \\
\hline S. muticum (10) & 83 & 55 & 77 & 58 & 78 & 75 \\
\hline E. siliquosus (11) & 77 & 73 & 81 & 53 & - & - \\
\hline A. esculenta (12) & - & - & - & - & - & - \\
\hline C. filum (13) & - & - & - & - & - & - \\
\hline L. digitata (14) & - & - & - & - & - & - \\
\hline L. ochroleuca (15) & 69 & 65 & 33 & 21 & 37 & 27 \\
\hline S. polyschides (16) & - & - & - & - & - & - \\
\hline C. crispus (17) & 82 & 51 & 77 & 51 & 69 & 63 \\
\hline G. stellata (18) & - & - & - & - & - & - \\
\hline G. Iatifolium (19) & - & - & - & - & - & - \\
\hline P. palmata (20) & - & - & - & - & - & - \\
\hline D. carnosa (21) & - & - & - & - & - & - \\
\hline B. secundiflora (22) & - & - & - & - & - & - \\
\hline C. rubrum (23) & 9 & 5 & 34 & 30 & 45 & 26 \\
\hline C. ramosa (24) & 13 & 9 & 41 & 27 & 17 & 12 \\
\hline D. sanguinea (25) & - & - & - & - & - & - \\
\hline G. floculosa (26) & - & - & - & - & - & - \\
\hline H. equisetifolius (27) & - & - & - & - & - & - \\
\hline L. pinnatifida (28) & 35 & 28 & 6 & 4 & 31 & 29 \\
\hline P. elegans (29) & - & - & - & - & - & - \\
\hline P. lanosa (30) & 81 & 57 & 12 & 11 & 88 & 59 \\
\hline
\end{tabular}

-: no inhibition 
Table 8 : Effect of ethanolic (B) extracts $\left(300 \mu \mathrm{g} \cdot \mathrm{mL}^{-1}\right)$ on the attachment rate (AR) and of the germination rate (GR) on spores of macroalgae after 5 days of incubation.

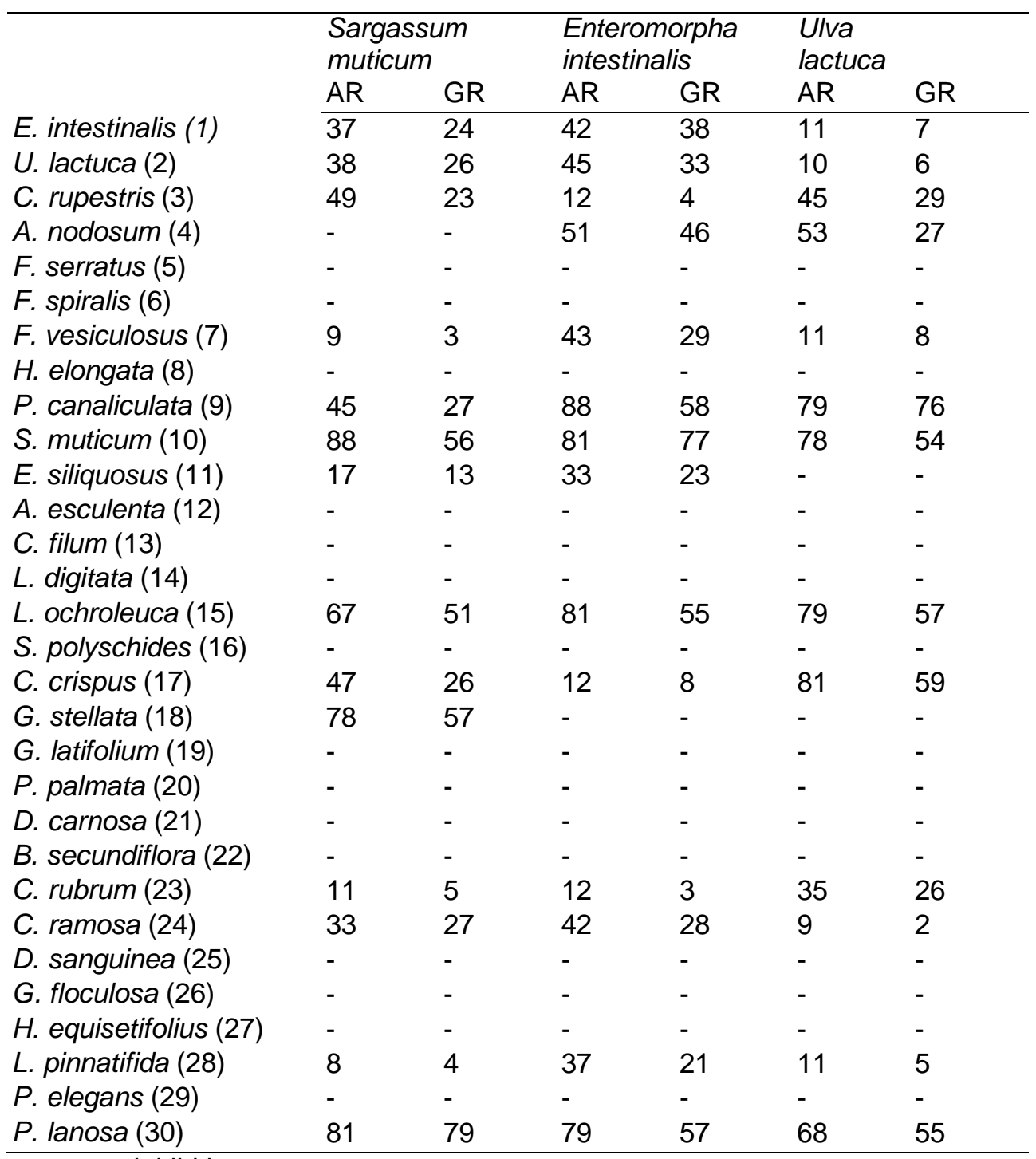

- : no inhibition 
Table 9: Effect of the methylene chloride (C) extracts $\left(300 \mu \mathrm{g} \cdot \mathrm{mL}^{-1}\right)$ on the attachment rate (AR) and of the germination rate (GR) on spores of macroalgae after 5 days of incubation

\begin{tabular}{|c|c|c|c|c|c|c|}
\hline & \multicolumn{2}{|c|}{$\begin{array}{l}\text { Sargassum } \\
\text { muticum }\end{array}$} & \multicolumn{2}{|c|}{$\begin{array}{l}\text { Enteromorpha } \\
\text { intestinalis }\end{array}$} & \multicolumn{2}{|c|}{$\begin{array}{l}\text { Ulva } \\
\text { lactuca }\end{array}$} \\
\hline & AR & GR & AR & GR & AR & GR \\
\hline E. intestinalis (1) & - & - & 7 & 3 & 33 & 28 \\
\hline U. lactuca (2) & - & - & 12 & 4 & 41 & 27 \\
\hline C. rupestris (3) & - & - & 78 & 55 & 12 & 5 \\
\hline A. nodosum (4) & 39 & 21 & - & - & 77 & 56 \\
\hline F. serratus (5) & - & - & - & - & - & - \\
\hline F. spiralis (6) & - & - & - & - & - & - \\
\hline F. vesiculosus (7) & 38 & 23 & - & - & 35 & 21 \\
\hline H. elongata (8) & - & - & - & - & - & - \\
\hline P. canaliculata (9) & 87 & 59 & 79 & 73 & 46 & 28 \\
\hline S. muticum (10) & 83 & 55 & 76 & 73 & 81 & 58 \\
\hline E. siliquosus (11) & 41 & 29 & - & - & 71 & 51 \\
\hline A. esculenta (12) & - & - & - & - & - & - \\
\hline C. filum (13) & - & - & - & - & - & - \\
\hline L. digitata (14) & - & - & - & - & - & - \\
\hline L. ochroleuca (15) & 13 & 9 & 32 & 17 & 11 & 7 \\
\hline S. polyschides (16) & - & - & - & - & - & - \\
\hline C. crispus (17) & - & - & 81 & 78 & 11 & 4 \\
\hline G. stellata (18) & - & - & - & - & - & - \\
\hline G. Iatifolium (19) & - & - & - & - & 71 & 70 \\
\hline P. palmata (20) & 69 & 65 & - & - & - & - \\
\hline D. carnosa (21) & 81 & 78 & 77 & 75 & 69 & 63 \\
\hline B. secundiflora (22) & - & - & - & - & - & - \\
\hline C. rubrum (23) & 31 & 22 & 37 & 21 & 11 & 3 \\
\hline C. ramosa (24) & - & - & 12 & 2 & 35 & 26 \\
\hline D. sanguinea (25) & - & - & - & - & - & - \\
\hline G. floculosa (26) & - & - & - & - & - & - \\
\hline H. equisetifolius (27) & - & - & - & - & - & - \\
\hline L. pinnatifida (28) & 33 & 25 & 34 & 27 & 38 & 23 \\
\hline P. elegans (29) & - & - & - & - & - & - \\
\hline P. lanosa (30) & 87 & 86 & 81 & 55 & 83 & 80 \\
\hline
\end{tabular}

- : no inhibition 
Table 10 : Determination of the $L C_{50}$ values (in $\mu \mathrm{g} / \mathrm{mL}$ ) on oysters and sea urchins larvae.

\begin{tabular}{|c|c|c|}
\hline & $\begin{array}{l}\mathrm{LC}_{50} \text { for sea urchins } \\
\text { larvae }\end{array}$ & $\begin{array}{lll}\mathrm{LC}_{50} & \text { for } & \text { oysters } \\
\text { larvae } & & \end{array}$ \\
\hline $\mathrm{CuSO}_{4}$ & 46 & 14 \\
\hline TВTO & 7 & 4 \\
\hline $1 \mathrm{~A}$ & 313 & 71 \\
\hline $2 A$ & $>800$ & 222 \\
\hline $2 B$ & 462 & 75 \\
\hline $2 C$ & 116 & 71 \\
\hline $9 A$ & 375 & 72 \\
\hline $10 \mathrm{~A}$ & $>800$ & 215 \\
\hline $11 \mathrm{~A}$ & 499 & 7 \\
\hline $11 B$ & 102 & 71 \\
\hline $11 C$ & 125 & 68 \\
\hline $18 \mathrm{~B}$ & 76 & 64 \\
\hline $21 B$ & $>800$ & 227 \\
\hline $21 C$ & 387 & 66 \\
\hline $26 B$ & 337 & 62 \\
\hline
\end{tabular}

Extracts 1B, 1C, 3A, 3B, 3C, 4A, 4B, 4C, 5A, 5B, 5C, 6A, 6B, 6C, 7A, 7B, 7C, 8A, 8B, 8C, 9B, 9C, 10B, $10 \mathrm{C}, 12 \mathrm{~A}, 12 \mathrm{~B}, 12 \mathrm{C}, 13 \mathrm{~A}, 13 \mathrm{~B}, 13 \mathrm{C}, 14 \mathrm{~A}, 14 \mathrm{~B}, 14 \mathrm{C}, 15 \mathrm{~A}, 15 \mathrm{~B}, 15 \mathrm{C}, 16 \mathrm{~A}, 16 \mathrm{~B}, 16 \mathrm{C}, 17 \mathrm{~A}, 17 \mathrm{~B}, 17 \mathrm{C}, 18 \mathrm{~A}$, 18C, 19A, 19B, 19C, 20A, 20B, 20C, 21A, 22A, 22B, 22C, 23A, 23B, 23C, 24A, 24B, 24C, 25A, 25B, 25C, 26A, 26C, 27A, 27B, 27C, 28A, 28B, 28C, 29A, 29B, 29C, 30A, 30B \& 30 C exhibited $\mathrm{CL}_{50}>800 \mu \mathrm{g} / \mathrm{mL}$ against oysters and sea urchins larvae. 